\title{
Toward a relevant agenda for warehousing research: literature review and practitioners' input
}

\author{
Hoda Davarzani · Andreas Norrman
}

Received: 11 November 2014/ Accepted: 4 December 2014/Published online: 10 January 2015

(C) The Author(s) 2014. This article is published with open access at Springerlink.com

\begin{abstract}
The main purpose of this research is to provide an agenda for future warehousing research relevant for both academic development and practitioners' needs. In order to suggest a practically relevant future research agenda, first a comprehensive literature review was performed to identify research areas covered in the literature. Then, 15 warehouse managers and senior consultants were interviewed to add empirical input to the development of potential future research areas. The literature review reveals gaps, both methodology- and topic-wise. A considerable methodological imbalance is observed. Some of the highlighted managerial concerns have been investigated in the literature extensively, but the managerial concerns emphasized mostly do not belong to the most researched categories. While most of the practitioners' concerns relate to supportive aspects of warehousing business, a relatively high number of the reviewed studies highlight operational problems. The suggested future research agenda highlights the importance of supportive aspects of the warehousing business, employment of real data in analysis and empirical research methods. The insights from practitioners stress the expected trends of business environment such as more volatile demand, higher
\end{abstract}

Electronic supplementary material The online version of this article (doi:10.1007/s12159-014-0120-1) contains supplementary material, which is available to authorized users.

H. Davarzani $(\bowtie)$

Discipline of Business Analytics, University of Sydney Business

School, Sydney, Australia

e-mail: hoda.davarzani@sydney.edu.au

H. Davarzani · A. Norrman

Department of Industrial Management and Logistics, Lund

University, Lund, Sweden

e-mail: andreas.norrman@tlog.lth.se desire for customized services and more expansion of e-commerce.

Keywords Literature review - Research agenda . Warehousing $\cdot$ Material handling

\section{Introduction}

Warehousing is one function in the logistics process that most products flow through. As competition for many markets is spelled as "faster," "cheaper," "broader assortment," "more customized," "home delivery," etc. and markets at the same time are becoming more global, those requirements will also impact a logistics function like warehousing. Furthermore, different requirements from different sales channels (e-commerce, retail, indirect channels, omni-channels), from different production philosophies (e.g., lean or agile), different managerial perspectives (e.g., economic efficiency, green performance and social responsibility), and the choice between old and new technologies [e.g., radio frequency identification device (RFID) and bar coding, different degrees of automation, decentralized control, cyber-physical systems, voice picking, warehouse management systems (WMS), etc.] impose challenges and opportunities for the warehousing operations.

Carter [1] argues that the gap between research and practice is generated because either the produced knowledge is not relevant to managerial needs or it is not transferred in a proper way. He defines the term of relevance to be "creating knowledge that managers can use to better understand phenomena relating to that which they manage."

Previous literature studies in the warehousing field have been done by $\mathrm{Gu}$ et al. [2, 3]. They covered different 
aspects of warehouse design, operation and performance evaluation. In total, 197 articles and books formed the source of their review. Although these literature review papers are properly representative of the publications before 2000 , only around $10 \%$ of the reviewed works were published in the past decade.

Carter's [1] argument on relevance of the research and lack of recent literature studies in warehousing field drive our interest in what research is currently being done, and what is needed, to support logistics managers in their future challenges regarding warehousing. Therefore, the purpose of this paper was to identify a future agenda for relevant warehousing research, based on both academic and practitioner interest.

This study is done from a logistics and operations management perspective, and its scope is limited to warehouse operations and internal support activities such as warehouse design, performance evaluation, human resource management, as well as direct interfaces to other departments or companies. However, this research does not include inventory management, network design, location planning and engineering aspects.

The remaining parts of this paper are organized as follows: First, a brief overview on research method is provided. Second, the literature is analyzed based on a proposed framework. Third, the results of interviews with practitioners are presented to describe their main concerns and views on future warehousing trends. Fourth, the similarities and differences between scholars and practitioners are discussed. Finally, the paper concludes with suggestions for future research agendas and a brief summary.

\section{Research method}

To identify future opportunities for warehousing research, based on both academic and practitioner interest, we start by investigating the current research frontier and academic research proposals through a literature study. Literature review studies have two goals: to map and evaluate the body of the literature in one specific field and to identify the gaps to develop the borders of knowledge in that certain area [4]. Rowley, Slack [5] propose that a literature study should be done in following steps: scanning resources, designing the mind map to structure the literature review, writing the study and building the bibliography. This approach is followed here. Performing a literature study is done through an iterative cycle of defining new key words, searching the literature and carrying out the analysis [6]. As our purpose is to identify future opportunities for research, we focus on publications from the past decade in the journals indexed by Scopus, one of the biggest databases for abstract and citation of research works. It currently covers more than 21,000 peer-reviewed journals including the journals published by Elsevier, Emerald, Informs, Taylor and Francis, Springer and Inderscience.

A primary search of research articles in Scopus, using different keywords (see Table 1) resulted in 955 papers. Refining the papers found based on the focus of this work limited the task to 243 peer-reviewed articles. These papers were published in a wide range of 104 different journals, with different scopes. However, nine journals included almost half of the papers: International Journal of Production Research (30), IIE Transactions (Institute of Industrial Engineers) (16), European Journal of Operational Research (16), International Journal of Production Economics (13), Computers and Industrial Engineering (11), International Expert Systems with Applications (10), Ergonomics (8), International Journal of Physical Distribution and Logistics Management (7) and The International Journal of Logistics Management (5).

The review focuses on the methodology employed, the content discussed and the suggestions proposed for future research. Scanning the previous literature reviews, complemented with the textbook by Bartholdi and Hackman [7], let us define categories, keywords and finally a conceptual map/framework to classify and analyze the literature. This framework is based on primary entities (warehouse operations like receive, store, pick, pack and ship products) and supportive entities (strategy, infrastructure design, human resource management, technology and performance evaluation), as well as interfaces to other department/organizations (Fig. 1; numbers in parentheses state the number of papers reviewed relating to each category. Some of the papers could be considered in more than one category).

Warehousing is a critical component of the supply chains with the responsibility to receive, store, pick, pack and ship stock keeping units (SKUs) between suppliers and

Table 1 Keywords in different stages

\begin{tabular}{cc}
\hline $\begin{array}{c}\text { Phase (1)_keywords for } \\
\text { primary search }\end{array}$ & $\begin{array}{c}\text { Warehouse, material handling, material } \\
\text { handling, distribution center, } \\
\text { distribution center, cross-dock, cross- } \\
\text { dock; AND NOT IN TITLE (data } \\
\text { warehousing, data warehouse) }\end{array}$ \\
& Two warehouse, inventory, lot sizing, \\
Phase (2)_exclusion & network design, location, location \\
keywords & allocation, manufacturing cell, FMS, \\
& flexible manufacturing, automated \\
& manufacturing, flow shop, job shop, \\
& robotic cell, machine shop \\
& Picking method, picking path, order \\
& batching, AS/RS, storage/retrieval, \\
storage location, storage method, order & batching, picking performance, storage \\
complementary & performance, warehouse design, \\
keywords & warehouse safety \\
\hline
\end{tabular}


customers. The supplier and customer can be external companies or other departments in the same company. In order to run the core operations of a warehouse, different supporting activities should also be included. Warehousing should follow a proper strategy that determines the overall guidelines of how operations are conducted; the design of the warehouse needs to be suitable for warehousing activities and assure performance; resources such as space, employees, equipment and technologies should be provided to run the business as planned. In addition, the performance of the system needs to be evaluated either aggregated or within detailed operations. Finally, the relation with other companies and departments should be managed to increase efficiency and effectiveness of the warehouse.

Fig. 1 Framework for warehousing research categories

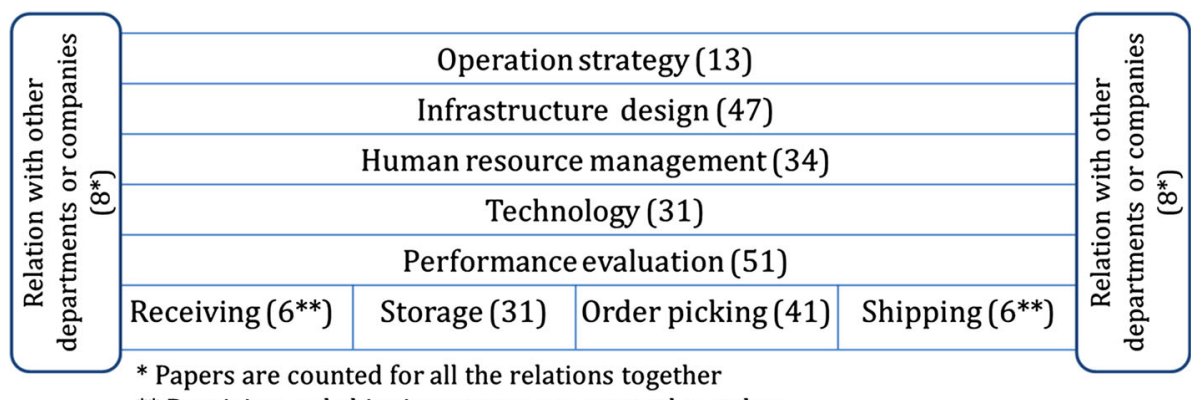

** Receiving and shipping papers are counted together

Table 2 Number of papers in the top nine journals based on the categories classification

\begin{tabular}{|c|c|c|c|c|c|c|c|c|c|c|}
\hline \multirow[t]{2}{*}{ Journal } & \multicolumn{10}{|c|}{ Research category } \\
\hline & $\begin{array}{l}\text { Operation } \\
\text { strategy }\end{array}$ & Infrastructure & $\begin{array}{l}\text { Human } \\
\text { resource }\end{array}$ & Technology & Performance & $\begin{array}{l}\text { Receiving/ } \\
\text { shipping }\end{array}$ & Storage & Picking & Connection & Total $^{\mathrm{a}}$ \\
\hline $\begin{array}{l}\text { International } \\
\text { Journal of } \\
\text { Production } \\
\text { Research }\end{array}$ & 5 & 12 & & 1 & 2 & & 6 & 9 & & 35 \\
\hline $\begin{array}{c}\text { International } \\
\text { Journal of } \\
\text { Production } \\
\text { Economics }\end{array}$ & 2 & 2 & 1 & & 4 & & 5 & 3 & 1 & 18 \\
\hline $\begin{array}{l}\text { IIE Transactions } \\
\text { (Institute of } \\
\text { Industrial } \\
\text { Engineers) }\end{array}$ & & 6 & 1 & & 4 & & 3 & 4 & & 18 \\
\hline $\begin{array}{l}\text { European Journal } \\
\text { of Operational } \\
\text { Research }\end{array}$ & 1 & 2 & & & 1 & 1 & 2 & 5 & 2 & 14 \\
\hline $\begin{array}{l}\text { Computers and } \\
\text { Industrial } \\
\text { Engineering }\end{array}$ & & 1 & & 3 & 3 & 1 & 2 & 3 & 1 & 14 \\
\hline $\begin{array}{l}\text { Expert Systems } \\
\text { with } \\
\text { Applications }\end{array}$ & 2 & & 1 & 3 & & 1 & 1 & 2 & 2 & 12 \\
\hline $\begin{array}{l}\text { International } \\
\text { Journal of } \\
\text { Physical } \\
\text { Distribution and } \\
\text { Logistics } \\
\text { Management }\end{array}$ & 1 & & 2 & 2 & 4 & & 1 & & & 10 \\
\hline Ergonomics & & & 8 & & & & & & & 8 \\
\hline $\begin{array}{l}\text { The International } \\
\text { Journal of } \\
\text { Logistics } \\
\text { Management }\end{array}$ & 3 & & & 2 & & & & & & 5 \\
\hline
\end{tabular}

a Some papers are related to more than one category 
The spread of papers for each category in the most frequent journals is presented in Table 2. The distribution of the top nine journals' articles within different categories is quite similar to the distribution of all papers we reviewed.

Inspired by Carter [1] arguments regarding research relevant for managers, we follow up the literature review with practitioner interviews to be able to also incorporate their views and insights into the research agenda. Baker and Canessa [8], Thomas et al. [9] and Sodhi et al. [10] have employed a similar method through combining literature studies and focus group/interviews with experts and practitioners to define potential opportunities of research with practical relevance. Many academics in the logistics and warehousing field have a close and regular collaboration with practitioners. Some of the well-reputed conferences (i.e., Council of Supply Chain Management Professionals, Warehousing Education and Research Council, International Material Handling Research Colloquium) have also facilitated this interaction. One of the reasons for the required tie between academics and practitioners is to achieve higher managerial and practical relevance for the scholarly research projects. By employing two methods, both a literature review and analysis of practitioners' insights, the suggestions for future research are not solely based on the identified gaps in the literature but also consider the input from industry. Hence, more practically relevant future research directions can be suggested.

Fifteen warehouse managers and senior consultants were interviewed with the main questions concentrating on their common and important concerns in different aspects of the warehousing business (Appendix A of ESM). All the interviewees (Table 3) were selected with the purpose to have a broad range of specialties. For instance, the consultants interviewed were chosen to cover strategic, operational and technical expertise to prevent bias in results. The selection was a convenience sample with half of the respondents from Australia and half from Sweden. Most of the companies were international with global activities. We did not see any significant differences in the answers from the countries and think they could indicate answers from practitioners in developed countries. Anyhow, performed interviews are not enough to build the foundation for theory building, but can provide a "springboard" for future research [11].

Questions were open to let the respondents describe all their thoughts. According to their familiarity and involvement with warehousing management issues, participants were able to elaborate potential concerns from different angles. Interviews were recorded, transcribed and sent for confirmation. Twenty-nine potential concerns were identified by analyzing interviews, and these concerns are elaborated in Sect. 4. The approved transcriptions were
Table 3 List of the interviewed practitioners

\begin{tabular}{|c|c|c|c|}
\hline No. & Type of company & Title of position & $\begin{array}{l}\text { Years of } \\
\text { experience }\end{array}$ \\
\hline 1 & $\begin{array}{l}\text { Spare parts warehouse } \\
\text { for machinery }\end{array}$ & Warehouse manager & 21 \\
\hline 2 & $\begin{array}{l}\text { Management consulting } \\
\text { company A }\end{array}$ & Senior consultant & 13 \\
\hline 3 & $\begin{array}{l}\text { Management consulting } \\
\text { company B }\end{array}$ & Senior consultant & 22 \\
\hline 4 & $\begin{array}{l}\text { Management consulting } \\
\text { company C }\end{array}$ & Region director & 12 \\
\hline 5 & $\begin{array}{l}\text { Management consulting } \\
\text { company } \mathrm{C}\end{array}$ & Senior consultant & 4 \\
\hline 6 & $\begin{array}{l}\text { IT solutions consulting } \\
\text { company }\end{array}$ & $\begin{array}{l}\text { Business relation } \\
\text { manager }\end{array}$ & 17 \\
\hline 7 & $\begin{array}{l}\text { IT solutions consulting } \\
\text { company }\end{array}$ & Product manager & 14 \\
\hline 8 & $\begin{array}{l}\text { Food and vegetable } \\
\text { retailer }\end{array}$ & $\begin{array}{l}\text { Operational } \\
\text { excellence manager }\end{array}$ & 15 \\
\hline 9 & Paper and packaging & Warehouse manager & 18 \\
\hline 10 & Beverage business & $\begin{array}{l}\text { Warehouse } \\
\text { coordinator }\end{array}$ & 7 \\
\hline 11 & $\begin{array}{l}\text { Heating, ventilation and } \\
\text { air conditioning }\end{array}$ & $\begin{array}{l}\text { Warehouse system } \\
\text { manager }\end{array}$ & 15 \\
\hline 12 & Pharmaceutical company & Logistics manager & 14 \\
\hline 13 & $\begin{array}{l}\text { Third-party logistics } \\
\text { service provider }\end{array}$ & $\begin{array}{l}\text { Warehouse and } \\
\text { business } \\
\text { development } \\
\text { manager }\end{array}$ & 20 \\
\hline 14 & $\begin{array}{l}\text { Kitchen and laundry } \\
\text { appliances }\end{array}$ & $\begin{array}{l}\text { National warehouse } \\
\text { manager }\end{array}$ & 16 \\
\hline 15 & $\begin{array}{l}\text { Food and vegetable } \\
\text { retailer (incl. internet } \\
\text { shopping) }\end{array}$ & $\begin{array}{l}\text { Logistics operations } \\
\text { manager }\end{array}$ & 13 \\
\hline
\end{tabular}

analyzed to find the core areas of managerial concerns. In order to identify theory-practice gaps, respondents' concerns were checked against the literature to see whether any of the reviewed papers have covered them. In addition, frequency of the concerns mentioned and weight of related literature category were compared to evaluate their correspondence.

\section{Literature review}

The literature review shows that the most commonly employed research method (Table 4) is mathematical modeling where no real-case data are used $(51.9 \%$ of reviewed papers). Research based on empirical case studies (13.6\%) or using real data as input to modeling (21\%) is less frequent. Most of the case study papers fit into the category of warehousing operation strategy and cover highlevel decision- and policy-making activities. Real-case data 
Table 4 Classification of the reviewed papers based on research category and the method employed a Most of the literature review papers had broad coverage, so they were not classified into any of the research categories

\begin{tabular}{|c|c|c|c|c|c|c|c|}
\hline \multirow{2}{*}{$\begin{array}{l}\text { Research } \\
\text { category }\end{array}$} & \multicolumn{7}{|l|}{ Research method } \\
\hline & $\begin{array}{l}\text { Mathematical } \\
\text { modeling with } \\
\text { test data }\end{array}$ & $\begin{array}{l}\text { Real-case } \\
\text { data and } \\
\text { context }\end{array}$ & $\begin{array}{l}\text { Simulation } \\
\text { methods }\end{array}$ & $\begin{array}{l}\text { Case } \\
\text { study and } \\
\text { empirical } \\
\text { example }\end{array}$ & Survey & Conceptual & $\begin{array}{l}\text { Literature } \\
\text { review }\end{array}$ \\
\hline $\begin{array}{c}\text { Operation } \\
\text { strategy }\end{array}$ & 3 & 3 & & 10 & & 1 & \\
\hline $\begin{array}{l}\text { Infrastructure } \\
\text { design }\end{array}$ & 29 & 3 & 9 & 3 & & 3 & 1 \\
\hline $\begin{array}{l}\text { Human resource } \\
\text { management }\end{array}$ & 10 & 13 & 3 & 4 & 6 & 3 & \\
\hline Technology & 15 & 8 & 7 & 6 & 2 & 2 & \\
\hline $\begin{array}{c}\text { Performance } \\
\text { evaluation }\end{array}$ & 18 & 7 & 9 & 7 & 9 & 1 & \\
\hline $\begin{array}{l}\text { Receiving/ } \\
\text { shipping }\end{array}$ & 1 & 4 & 2 & 1 & & & \\
\hline Storage & 19 & 6 & 9 & & & & \\
\hline Picking & 28 & 5 & 9 & 2 & & & \\
\hline $\begin{array}{l}\text { Connection to } \\
\text { other } \\
\text { departments/ } \\
\text { companies }\end{array}$ & 3 & 2 & 1 & & 1 & 1 & \\
\hline Uncategorized $^{\mathrm{a}}$ & & & & & & & 5 \\
\hline Total (\%) & 51.9 & 21.0 & 20.2 & 13.6 & 7.4 & 4.5 & 2.5 \\
\hline
\end{tabular}

are mostly used in research related to the effects of material handling activities on personnel health in the human resource management category. Appendix B of ESM presents how the papers and their outlets (major journals) are classified due to methods employed.

This observed imbalance between methods employed, and the gap between desk studies and the practitioners' world, raise questions like (a) how could research be more directly connected to business, (b) why are different methods not applied to more categories, and (c) how useful can the mathematical models developed without "real data" be for practitioners?

The reviewed literature will now be discussed in greater detail based on content, in the order following the suggested framework (Fig. 1).

\subsection{Operation strategy}

By operation strategy, we mean both strategic planning and general operational policies. Detailed operational planning would fit to the scope of research related to each operation, namely receiving, storage, picking and shipping. Examples of operation strategies and policies are decision making on managerial philosophies [12], outsourcing [13], material flow pattern and FIFO versus LIFO [14].

In addition to the strategic decisions, appropriate operation policies should be devised. Different researchers have worked on the proper utilization of technologies to support the overall strategy: for example, employment of a WMS in cooperation with RFID technology [15] and decision support systems [16].

The distribution of the papers between the two categories of strategic planning and operational policy making is similar. Most of the studies focus on unit-load warehouse, while research on less than unit load is scarce and adds more complications to the analysis. Most of the published works are under deterministic conditions, although the business environment contains a lot of uncertainties and risks.

\subsection{Infrastructure design}

Many papers cover different aspects of infrastructure design including estimations of required space [17], layout design and determination of departments' location relative to each other [18], department design [19] and equipment configuration [20]. Most of the papers reviewed in this category follow a mathematical modeling research method, and more specifically the majority of the solution techniques are meta-heuristic algorithms.

The other group of papers in this field is focusing on determining location and size of warehouse departments. Most of the published papers in this field try to capture other aspects in their models as well, such as designing the 
operation [21] and product allocation to different departments [22]. Multiple-level layout design is one of the most complicated problems in the literature [23]. The more detailed studies are those concentrating on design of the warehouse area, e.g., configuration of lanes in picking/ storage areas [24]. Apart from the layout of the departments, configuration of warehouse equipment is another area of the literature [20]. Finally, very few papers investigate warehouse construction and design from energy efficiency perspective [25-27].

Infrastructure design is one of the richest categories in the literature. Several aspects including sizing, dimensioning, department design and configuration of equipment are covered. Research on warehouses with special needs, such as temperature-controlled departments and high seasonality, is relatively scarce. The majority of the literature approach warehouse design problem from economic efficiency perspective, while research with special consideration to environmental performance is scarce. Most of the design papers focus on the storage departments, while research on the layout of receiving and shipping is rare; these departments are more important for a cross-dock warehouse, another field of research which seems to be overlooked in the literature.

\subsection{Human resource management}

Human resource management can be investigated from different angles. Scheduling of the staff [28], psychological considerations [29], and ergonomics issues and safety [30] are the main areas explored in the literature. Chakravorty [31] posits that academic research in warehousing and material handling is mainly focused on technical factors to improve performance, but usually neglects human factors.

Ergonomics of warehousing jobs is the most investigated topic in human resource management. Such research can be useful when designing material handling equipment. Even the way that male and female operators [32] and expert and non-expert workers [33] are performing can be different. Awareness regarding such differences would be helpful not only in design of the equipment but also in job assignment in the warehouses.

The reviewed literature shows that human resource management has been considered mainly from an ergonomics point of view, i.e., how handling of different items can have negative impact on the body. Apart from that, researchers have also explored impact of exposure to carbon monoxide from equipment, job rotation and psychological aspects of warehousing work, even though their proportions have been significantly less. Scheduling and rotation of tasks in warehouses are among the everyday work in most of the warehouses and distribution centers, but have not attracted much research.

\subsection{Technology and equipment}

Within this category, two groups of soft and hard technology/equipment are considered. Selection of automation level [34], appropriate equipment [35], suitable warehousing management system [36], decision support systems [37], planning and application of those technologies and equipment [38] are included in this group of research. Among the technologies introduced in warehousing is tracking equipment such as RFID-based devices or barcodes. Some researchers have shown cost and time efficiency of employing such technologies [39], although some skepticism exists on the potential cost-saving capabilities and positive ROI in the near future for RFID [40]. Designing a proper WMS for a warehouse is also an important aspect to consider. Even though such works are not very common in academic research, Shiau and Lee [36] design a WMS to integrate picking and packing operations. Employment of automatic guided vehicles (AGV) in warehousing has become very popular during last decade. This trend can also be witnessed in the literature [41-43], but most of the relevant papers can be found in robotic and mechatronic literature with more emphasis on engineering aspects.

The automation and equipment category of research addresses the problems of choosing the level of required automation and suitable equipment/technology. Among the most recent research are those that consider emission level as one of the factors influencing the choice of appropriate equipment [44]. This is a strategic decision that can significantly affect the investment level, financial outcome and operational performance of the warehouse. This category of research has been studied more extensively after 2000 than before (see Table 5). Most of the scholarly research focuses on the soft technologies and how their employment can influence warehouse performance.

\subsection{Performance evaluation}

Performance evaluation is a critical activity in every business. It provides useful feedback on performance and potential impact of infrastructure design, operational policy and improvement methods. This category includes all publications with the main objective of performance evaluation, measurement and improvement. This evaluation can be considered on three different levels:

1. Overall performance of a warehouse: e.g., development of an AHP-DEA model to compare performances of different warehouses [45], or a structural equations model to evaluate the logistics capability [46].

2. Performance of a department or specific process: e.g., level of responsiveness based on order batching policy, 
Table 5 Number of the reviewed papers based on category and year

\begin{tabular}{|c|c|c|c|c|c|c|c|c|c|c|c|c|c|c|c|}
\hline Category/year & $<2000^{\mathrm{a}}$ & 2000 & 2001 & 2002 & 2003 & 2004 & 2005 & 2006 & 2007 & 2008 & 2009 & 2010 & 2011 & 2012 & Total $^{\mathrm{b}}$ \\
\hline Performance & 45 & 3 & & 5 & 4 & 4 & 4 & 2 & 6 & 3 & 7 & 2 & 8 & 2 & 95 \\
\hline Infrastructure & $33^{\mathrm{c}}$ & 3 & 2 & 7 & 1 & 1 & 3 & 5 & 3 & 4 & 4 & 4 & 5 & 5 & 80 \\
\hline Picking & 59 & 1 & 3 & 2 & 3 & 2 & 5 & 4 & 2 & 3 & 3 & 4 & 4 & 5 & 100 \\
\hline Human resource & $-{ }^{\mathrm{d}}$ & 2 & & 2 & 1 & & 3 & 5 & 5 & 5 & 2 & 5 & 3 & 3 & 36 \\
\hline Technology & 4 & 1 & 2 & 1 & & & 3 & 5 & 2 & 2 & 3 & 7 & 7 & & 37 \\
\hline Storage & 44 & 2 & 1 & 1 & 1 & 3 & 2 & 3 & 1 & 4 & 4 & 2 & 4 & 3 & 75 \\
\hline Operation strategy & 7 & 1 & & & & 1 & 1 & 2 & 1 & 2 & 1 & 3 & 1 & 3 & 23 \\
\hline Connection & $-{ }^{\mathrm{d}}$ & & 1 & & & & 1 & 2 & & 1 & & & 3 & 1 & 9 \\
\hline Receiving/shipping & 3 & & & & 1 & & & 2 & 1 & 1 & & & & 1 & 9 \\
\hline Total $^{\mathrm{b}}$ & 195 & 13 & 9 & 18 & 11 & 11 & 22 & 30 & 21 & 25 & 24 & 27 & 35 & 23 & \\
\hline
\end{tabular}

${ }^{\text {a }}$ Based on the research by $[2,3]$

b Some papers are related to more than one category

${ }^{c}$ Based on number of publications in three categories of overall structure, department layout and sizing and dimensioning in [3]

d These categories were not included in the research by $[2,3]$

capacity of the picking and sorting operations, and picking policy [47], and connection of warehouse design and order picking efficiency [48].

3. Performance of specific technology or equipment: e.g., evaluation of dual command mini-load throughput time [49], carousel throughput [50], AS/RS performance measurement by using queuing theory [51], travel time of tower crane $S / R$ machine under single and double cycle command [52].

This category was the most researched field after 2000, and it also had a quite high number of published papers in previous decades (Table 5). Most of the publications focus on the performance evaluation of a particular operation and equipment, and especially for automated warehouses. Studies with consideration to performance management and benchmarking of the successful cases can make significant contributions in future.

\subsection{Receiving and shipping}

The warehouse operations initiate in goods receiving and finish in the shipping area. Products are received into the warehouse, assigned to different locations, and after picking, they are packed and shipped out to the customers. The planning of receiving and shipping operations is among the least investigated topics in the literature. Some examples of potential problems to investigate are preparation of goods to be stored [53] and resource allocations, e.g., truck-dock assignment for receiving and delivery and order-truck assignment if orders of different customers are aggregated into one truck [54]. Receiving and shipping are the least investigated categories in the warehousing literature, with preparation operation and resource assignment as the main aspects explored.

\subsection{Storage}

Apart from inventory management, different decisions should be made to form the warehousing function, e.g., where SKUs should be stored in the warehouse [7]; how much space is required for each product [55]; what storage policy should be followed [56]; how products should be classified [57]; and how the scheduling and sequencing of operations should be planned [58]. Warehouse managers usually try to design storage processes in association with picking activities, because what is done in the storage stage directly influences the picking performance.

The operation of storage needs to be done based on a plan, and sometimes in combination with the picking process when the warehouse is working under double command operation. The estimation of average traveling time for multi-aisle AS/RS [59], sequencing the storage and picking in AS/RS system [60], scheduling the equipment in AS/RS system [61] and sequencing of storage and re-storage process [58] is among the published works in this field.

Unit-load and single-deep rack are the main setups for the publications in the storage category. Most papers belong to the subcategory of operational aspects, which includes more common problems of warehousing. Planning for the storage operation is one of the well-researched areas, but most publications neglect the dynamism of warehouse requirements and information. Employing robust planning can significantly contribute to this field.

\subsection{Picking}

Order picking is the most labor-intense operation in the warehouse [7]. Different picking strategies consist of some 
or all of the following activities: batching, routing, activities sequencing, sorting and packing. The picking activity can be done manually or with automated systems; both of these approaches require different models and planning. The reviewed literature can be categorized into the following areas.

1. Order picking policy: Evaluating the performance of different policies including single order picking, batch picking, zone picking and wave picking (e.g., [62]).

2. Order batching: Most of the published works in this area develop heuristic algorithms to solve batching problems. But Chen et al. [63] employ a data mining technique to develop a clustering procedure for orders of a warehouse with parallel-aisle layout.

3. Picker routing: For example, application of intelligent agent-based models to find picking routes in near real time [64], developing the picking route in a cross-aisle warehouse [65], in a multi-parallel-aisle warehouse [66] and picking sequence from different zones [56].

4. Automated picking operation: For example, routing and operations sequencing in automated warehouses [67] and positioning the dwell point (location of $S / R$ shuttle during idle time) in a unit-load AS/RS [68].

5. Combination of picking plan with other activities: For example, integrated problem of order batching and picking [69], and combination of order picking and packing operations [36].

Different picking methods are suggested in previous research, but we find that the literature lacks comprehensive analysis and comparison of these methods for different warehouse designs and operational requirements. Most of the papers consider travel/picking time as the main indicator to optimize when evaluating the picking operation. Finally, similar to the papers in the storage category, static information is the main mode of input for the problems addressed, while uncertainty of the business environment is usually neglected.

\subsection{Connection to other departments and companies}

Warehouses are connected to other departments and companies through both incoming and outgoing goods, and as a potentially outsourced function. This interface can be captured in different ways: e.g., by integration of planning and processes with purchasing, production, transportation and contracting with external companies.

Poon et al. [70] focus on the interface between production and raw material warehouse. Chou et al. [71] address a warehousing problem when products can be ordered from a production site and then after use are returned to the warehouses for future reuse. The connection of transportation and cross-dock warehouse operations is considered by Hill and Galbreth [72]. Contracting 3PL warehouses is becoming very common. As an example of analytical modeling of 3PL contracts, Chen et al. [73] formulate three different settings of warehousing contract with capacity commitment from buyer perspective and show which types can be cost-efficient to choose.

The relation of the warehouse to other departments and companies is among the least explored fields in the literature. Most of the papers in this category focus on the connection of warehouse and production to have a smooth flow of material between these two functions, especially when the material flow is from both sides. Two other investigated areas are contracting aspects and the connection with transportation, although not very extensively. As a summary of the literature discussed in this section, Appendix C of ESM exhibits the classification of each primary and supporting component and lists the related papers.

The status of warehousing research published before 2000 was extracted from $[2,3]$. They have a similar classification and definition for each category of research as in this paper, but the categories of human resource management and the connection to other companies/departments were not included. Comparing recent studies with those before 2000, most of older literature was devoted to operational aspects (storage and picking). Also performance evaluation attracted many publications as well as infrastructure design, in almost one-fifth of the total papers (Table 5). The three categories of technology and equipment, receiving/shipping and operations strategy are far behind with just 14 papers in total. Publications after 2000 are more evenly divided between different categories, although operations strategy, connection to other departments/companies and receiving/shipping are still significantly fewer. When comparing the number of papers in each category before and after 2000 , one observation is the increase of publications in the technology and equipment category. The trend of automation, rapid change and emergence of new soft/hard technologies, together with the e-commerce evolution during the last decade, can be some of the motivations for this increase. Another observation is the lower share of papers focusing on operational aspects. Even though the proportion of publications in these categories is still relatively high, it has decreased and become more similar to the supportive aspects.

\section{Practitioners' input}

Based on the qualitative analysis of the interview transcriptions, 39 potential concerns were identified that were classified based on the framework in Fig. 1. Table 6 summarizes these concerns according to the keywords used 
Table 6 Summary of the practitioners' input

\begin{tabular}{|c|c|c|c|}
\hline Categories and keywords & $\begin{array}{l}\text { No. of } \\
\text { people }\end{array}$ & Categories and keywords & $\begin{array}{l}\text { No. of } \\
\text { people }\end{array}$ \\
\hline Infrastructure & 12 & Performance evaluation (continued) & 11 \\
\hline Capacity limitation & 9 & Performance evaluation KPIs & 7 \\
\hline Inefficient use of space and improper zoning & 3 & Discrepancies (reasons and solutions) & 6 \\
\hline Inflexible layout & 1 & Technology and equipment & 13 \\
\hline Layout design & 1 & Automation flexibility & 5 \\
\hline Risk management at construction phase & 2 & Automation level & 4 \\
\hline Operation strategy & 9 & Transition phase in automation & 4 \\
\hline Globalization and cost reduction target & 2 & IT systems for e-commerce & 3 \\
\hline Demand for more customized services & 2 & $\begin{array}{l}\text { Inaccurate or inadequate } \\
\text { information on inventory }\end{array}$ & 4 \\
\hline Big fluctuations in demand & 1 & Improper WMS & 2 \\
\hline Goods assortment & 3 & Problems on shelving & 3 \\
\hline Slow movers & 5 & Inflexible equipment & 1 \\
\hline Short life SKUs & 1 & Picking & 3 \\
\hline $\begin{array}{l}\text { Changes of customers purchasing behavior } \\
\text { because of e-commerce }\end{array}$ & 2 & Consolidation aspects & 1 \\
\hline Operations and strategy for e-commerce & 3 & Picking optimization/route & 3 \\
\hline Human resources management & 9 & Storage & 2 \\
\hline Psychological aspects of warehousing work & 2 & Storage re-allocation & 1 \\
\hline Employees' health & 1 & Storage allocation & 1 \\
\hline Job satisfaction/motivation & 3 & Connection to others & 7 \\
\hline Updated training & 2 & Information sharing & 1 \\
\hline Rotation of jobs and how labor work & 4 & Connection to transport & 4 \\
\hline Performance evaluation & 11 & $\begin{array}{l}\text { IT support for connection to } \\
\text { transport }\end{array}$ & 1 \\
\hline Benchmarking & 2 & Connection to purchasing & 4 \\
\hline Activity based costing & 1 & $\begin{array}{l}\text { Common values and role of } \\
\text { the warehouse }\end{array}$ & 2 \\
\hline
\end{tabular}

by the interviewees and indicates how frequently each one was mentioned. The identified concerns are described below.

\subsection{Infrastructure design}

One common warehousing problem is related to space. This arises because of the growth in both volume and number of SKUs which, however, is not only a recent problem: "Our main issue is, and has been for a long time, the space problem. .... This issue has been here for so long, even as we have been using new techniques and new machinery to cope with it" (interviewee 1). "Space is the most common warehouse problem that can be fixed by right type of shelving and storage equipment. It will help you reduce the overhead expense, and increase the productivity" (interviewee 11). Interviewees 10, 11 and 15 highlight how improper storage systems, zoning and layout design increase the amount of space required. Another practitioner concern is risk management. Planning the expansion either through renting or buying the space requires proper risk management; interviewee 4 states "if you do not want to own a building then you want a company to rent it from, and I do not think there is a company to build and rent a warehouse if you want to put less than 7 years in the contract because financial risk is too great. But again from the company's perspective, it is a big risk to write a contract for 7 years, they do not know what may happen in 7 years in most industries."

\subsection{Operation strategy}

Global competition is continuously increasing for most companies. Having cheap labor gives them an important competitive advantage. "If we cannot keep our overhead down, we cannot compete with them. Doing less with more is what we should do" (interviewee 9). Having customers who expect more (interviewees 5, 9) calls for customized services that require proper planning and strategy development. The business trend toward more customized demands, order consolidation and big fluctuation in 
demand are examples of factors influencing operations planning approaches. Several interviewees $(4,8,9,12,15)$ raise the concern of slow movers, calling them one of the main cost drivers. Having said that, warehouse managers need an up-dated assortment of goods; "It is probably the easiest one to say but one of the most difficult ones to handle" (interviewee 4). As another aspect of modern business, e-commerce has been growing significantly during the past decade, and this trend will continue in the future. It is important to explore how this change can influence warehouses and their operations. In the words of interviewee 2, "instead of having major flows going to the bigger distributers, you actually need to start sending smaller parcels to customers. So, more and more, warehouses find that this is a different way of doing work; ... and there will still be a flow to normal stores." He continues, "Many warehouse managers may have thought about it but only a few have really adapted to this new way of distributing things"; the nature of material flow has changed and warehouses need to take the responsibility of sending goods to end customers in addition to shops and distribution centers.

\subsection{Human resource management}

The practitioners find it important to explore how the repetitive work of picking during a whole day influences workers and their performance. Occurrence of discrepancies may be one of the impacts. Research in this area is missing in the literature, but is in practitioners' interest, as interviewee 1 mentions: "That is probably a minor problem we have, which has been always spoken about as being a major problem"; "it would be very interesting to see how you can oil the mind of the picker, make work smoother and more correct; and not only correct but also faster, just by providing the right tools." In line with the goal of reducing discrepancies, interviewee 11 pinpoints the required training and motivation; interviewee 5 clarifies "there is a lot to do since in a warehouse you can see quite a lot of unmotivated personnel. I think a cultural change is needed here to lift the organization and individuals to be more productive by being happier and more content with work and their position." Employees' health is another important concern which is mentioned by interviewee 8 regarding cold storage area: "One problem is the sickness level of the labor which we think is high (6-7\%) and it costs both time and money to handle a high number like this"; he also continues from a staffing point of view: "we have an aim for a certain percentage of female employees but it is difficult due to the problem of having heavy work. It is not easy to handle all the weight. So what we do is that we try to rotate and we also use external labor on the heaviest parts."

\subsection{Technology and equipment}

The mentioned concerns can be divided into two groups of soft and hard technologies. Improper shelving and inflexible equipment can greatly hinder operations efficiency (interviewees 11, 13, 15). According to the interviewees, automation has been the trend for a long time. The more automated a warehouse becomes, the less flexible it can be. Combining partial flexibility and automation can be possible at huge cost, which stresses the importance of appropriate automation level. This balance point is sensitive to different parameters that need to be explored. As stated by interviewee 7 , "one of the main challenges with equipment and technology is to find the balance between implementation cost and flexibility," along with interviewee 6's perspective "with flexibility comes complexity." Automation has usually been suggested as the first solution for most warehouse problems, as interviewee 1 says: "I think that's why we are automated today, because someone told us that automation is the only way that speeds up picking; the latest technology was suggested instead of an analysis of what our real needs are." Furthermore, the automation process should be implemented, while the warehouse is working at full operation. This is consistent with ideas of interviewees 1, 2, 6 and 7, reporting that best practices during this transition time are valuable for warehouses. As a soft technology, properly designed WMS is required to provide accurate information on inventory and storage location, which can potentially reduce discrepancies (interviewees 9, 10, 13, 15). Finally, the evolution of e-commerce calls for critical changes in warehouse operations, strategies and requisite IT systems (interviewees 2, 7,9) to support operations.

\subsection{Performance evaluation}

The necessity of having well-defined KPIs is the most commonly expressed concern. It is important to establish correct understanding of the performance and measure it in the right way. Warehouse performance is usually measured based on the number of order lines, which most of the practitioners doubted to be the best measurement, as stated by interviewee 3: "It is important to measure the right thing. I mean it is not just the number of order-lines you pick per hour, it is also the matter of how much money is spent to pick an order-line." In addition, performance evaluation is critical when planning for improvement. KPIs should be able to show whether the changes have been made in the right direction based on the company goal for improvement. According to the numbers provided by interviewees $1,6,7,12,13$ and 14 , one of the areas that may be very small in number, but very huge in impact, is picking discrepancies. None of the interviewees mention it 
to be a severe problem for the warehouses, but they pointed out its huge potential impact because end customers directly feel it. Measuring these errors is important, but it is essential to find out why they happen, which in turn can lead to their reduction.

\subsection{Storage}

Warehouse operations are not so frequently mentioned in the interviews, although several practitioners voice their concern about operations strategy and planning. Two interviewees $(3,12)$ considered storage allocation and reallocation as their concern in the warehouse. Interviewee 12 mentions the warehouse problem during the recession: "almost all the warehouse slots were occupied and picking productivity was lower than before. Taking a walk around the warehouse, I realized we had products that I was not even aware of." In connection to this problem, he finds the solution in reviewing the inventory to recognize the dead items (obsolete SKUs), fast movers and re-allocation of storage places. According to interviewees 3 and 12, appropriate classification of the goods and storage location assignment play critical roles in warehouse operation cost.

\subsection{Picking}

According to the interviewed consultants, companies usually do not come to consultants with specific questions. Instead, the selling point is to secure a particular service level, capacity or cost, and "the most common thing that we look into is the picking process," said interviewee 4 . Picking is the most cost-driving activity in warehouses and needs to be explored. It is important to optimize the process to be smooth and cost-efficient throughout the whole year as well as during peak times.

\subsection{Connection to other departments and companies}

Interviewee 1 states, "Looking at the space issue, the link between the purchasing department and the warehouse is not very good. There has never been any real cooperation; just buying and then shipping to the warehouse; and then of course you have the other end which is the sales department." Similar to purchasing and sales department, production and transportation must be planned in cooperation with the warehouse; interviewee 4: "there is a trend about shipping, on how warehouse is depending on transport. You see that many companies are starting with transport management system (TMS) or logistics management system (LMS), and they are also looking at planning. So, they are starting to look at them as one question. But the companies that are really doing that, they are not many." Information sharing plays a significant role in planning for cooperation of different departments. Companies should determine when and what information should be shared. Regarding this issue interviewee 2 states, "we started some sort of internal service level agreement; and when we got there, it was easier to work and understand when we had an issue." Interviewees 8 and 11 point out that in order to set up such cooperation, members of the chain and different departments of a company should share common values; they need to have some knowledge about how the business works and how they can improve it by better collaboration.

\section{Toward a relevant research agenda based on the two perspectives}

To identify future opportunities for relevant warehousing research, we compared the concerns identified by interviewees with those in the literature. This comparison indicates how well practitioners' concerns are met by research and the research opportunities our study reveals.

Figure 2 highlights how frequently different concerns were mentioned by practitioners, and it also shows the literature focus according to the proportion of papers concentrating on each category. Reviewing this figure, one observation is that some of the highlighted managerial concerns have also been extensively investigated in the literature, although the most popular managerial concerns
Fig. 2 Comparing practitioners' concerns and literature focus

\begin{tabular}{|lr|rl|}
\hline \multicolumn{1}{|c|}{ literature (out of 243) } & practitioners (out of 15) \\
\hline Infrastructure design (47*) & $20 \%$ & $80 \%$ Infrastructure design (12**) \\
Operation strategy (16) & $7 \%$ & $60 \%$ Operation strategy (9) \\
Human resource (36) & $15 \%$ & $60 \%$ Human resource (9) \\
Technology \& equipment (33) & $14 \%$ & $87 \%$ Technology \& equipment (13) \\
Performance Evaluation (50) & $21 \%$ & $73 \%$ Performance Evaluation (11) \\
Picking (41) & $17 \%$ & $20 \%$ Picking (3) \\
Storage (31) & $13 \%$ & $13 \%$ Storage (2) \\
Receiving/Shipping (6) & $2 \%$ & $0 \%$ Receiving/Shipping (0) \\
Connection to others (8) & $\square$ & $4 \%$ & $47 \%$ Connection to others (7) \\
\hline
\end{tabular}

* Number of related papers in the literature (excluding literature review papers)

** Number of practitioners mentioning the related aspects 
are not the categories most studied. Most of the practitioners' concerns focus on supportive aspects of the warehousing business (e.g., infrastructure design, technology and equipment, performance evaluation) rather than operational aspects (picking, storage, shipping/receiving operations), while a relatively high number of the reviewed papers highlight operational problems.

\subsection{Comparing practitioners' concerns and literature}

Reviewing the practitioners' concerns and the literature, our findings are as follows:

\subsubsection{Infrastructure design}

Even though the literature is quite rich in this category, different investigations are still lacking. It is necessary to develop a systematic approach mapping the interaction between departments to enhance the process design. This design could improve by considering the requirements of operations, characteristics of SKUs and overall strategy, which are all dynamic. This dynamism is not considered in the proposed algorithms. Furthermore, literature is mainly devoted to the layout problem of stock keeping warehouses, and no research was found focusing on crossdocking warehouses. Finally, studies on design of shipping/ receiving areas are missing, while the main emphasis of the literature is on storage departments. Infrastructure design is the second most important concern of respondents. It is covered in different fields of literature, but it is not the most studied topic in any of them.

\subsubsection{Operation strategy}

Most of the publications consider unit-load warehouses, while planning for operational policy of less than unit-load warehouses is rare. As the business environment is rapidly changing, developing robust strategies can be very helpful for warehouse managers to assure a certain level of performance at uncertainty. It would be a great contribution to design scenarios for operation policies when data are scarce (which is usually the case in practice). Overall, there is a considerable number of publications, but in detailed subcategories, many managerial concerns are missing. Warehousing operations need to be planned so as to reduce discrepancies and provide the opportunity to track them. Many warehouses are trying to keep track of their operations and the employees responsible for each activity. But when the period of reporting these discrepancies is long, they cannot easily be confirmed and tracked back to find the root cause of the problem. Improvement of processes and information systems can facilitate the possibility of tracking back and confirming such errors. Finally, the emergence of e-commerce and its requirements is another aspect mentioned by the interviewees. Even though it has not been placed among the top ranked concerns, lack of the relevant scholar works draws our attention, considering suitable infrastructure and operational planning for this evolution. Operations need to be designed and planned to be able to fulfill the orders coming from both end customers and distribution centers, and each of these has its own characteristics and requirements.

\subsubsection{Human resource management}

The most investigated topic in this category is the ergonomics of manual material handling. The main focus of the literature is on physical impacts of the warehousing activities on employees, while interviewees highlighted psychological aspects. Based on the concerns raised by practitioners and literature gaps, it is necessary to study the working conditions in low temperature warehouses to see how the working environment can impact the performance of pickers and their health, to assist the scheduling plan of the staff. In addition, the trend of gender equity is an important factor to consider while planning for warehouse staffing and duty rotations, as was suggested by practitioners.

\subsubsection{Technology and equipment}

This category is the one most highlighted by practitioners and has had a sharp increase in the literature after 2000. In order to select appropriate technologies and equipment, three items should be defined: level of automation, requirements of the operations and appropriate selection criteria. Studies on unifying these three parts are required, showing how to define and integrate them. Practitioners emphasize different aspects related to automation, which does not correspond to the highly investigated research topics. Flexibility and level of automation are briefly covered in the literature, but the operational guide on the transition phase is an important missing piece. Warehouses need to change and implement automation, while they are working at full operation; identification of potential problems and solutions can help them to devise a roadmap for this change.

\subsubsection{Performance evaluation}

The highest portion of research is in the performance evaluation category, practitioners also found it very important. Some gaps could be found in the literature corresponding to practitioners' concerns. The importance of defining appropriate KPIs is well received by scholars, but a majority of published works lack empirical studies to 
address success stories. Benchmarking studies are scarce, and such research can be helpful to identify inefficiencies and propose improvements based on the successful cases investigated. In addition, the evaluation tools are mainly designed to measure the output of specific operations or equipment. Throughput analysis of different processes and operations must be investigated to identify bottlenecks and plan for overall improvement. Moreover, most of the tools and techniques addressed are customized for automated setup, which calls for studies on non-automated warehouses with higher levels of complexity because of the existence of human factors in the system.

\subsubsection{Receiving and shipping}

This category is the least explored in warehousing literature during the last decade, and practitioners also found very low interest in this area. One reason can be its low contribution in deriving costs for the warehouse in comparison with other operations (i.e., storage and picking). Papers on managing the receiving and shipping operations are very scarce, and most of the literature in this category focuses on resource assignment (e.g., truck and dock) independent from other operations in the warehouse. Receiving and shipping operations have the potential to be investigated more, independent from other operations and in integration with them. Before shipping, the picked and packed items are usually required to wait in the buffer zone until delivery time. Planning the shipping schedule in integration with picking can help save the required space for in-process items. This is particularly important for warehouses with severe space problems, as this was observed by one of the interviewees. Furthermore, integrated schedule planning of storage/picking and receiving/ shipping operations can provide the opportunity to assign staff more efficiently. Another potential opportunity for research is integration of dock assignment and receiving/ shipping schedule. Number of docks is limited, and if the transportation is not planned accordingly, the transport operators should wait until a vacant dock is available for loading/unloading. Integration of these two problems can make a considerable contribution to reducing the transport cost, because the transport operators charge companies for the waiting time as well as the operation. This integrated problem can be explored under setups of both separate and common docks for receiving and shipping operations.

\subsubsection{Storage}

Practitioners showed very low interest in this category. Only 2 out of 15 interviewees mentioned their potential concern about storage allocation and re-allocation. Most of the published research on determination of storage policy and location is dedicated to unit-load and single-deep rack setup. Further studies are required to address double/multiple deep racks and floor storage with multiple deep lanes. In order to apply class-based storage, products should be categorized into different classes based on different factors including their characteristics and storage/retrieval requirements, but this classification needs to be dynamic because of the classification parameters' dynamism. In addition, implementation of class-based storage must be elaborated, telling, for instance, what to do if the zone for one class of product is filled and an incoming shipment is assigned to that class. In most of the reviewed papers, planning for storage operation was done with the goal of minimizing picking time. Such studies can be extended to target less congestion and better spread of workload by considering replenishment operation during idle or nonpeak time. Extension of these studies can be on planning for restock time of the forward picking area.

\subsubsection{Picking}

This category is among the highlighted aspects in the literature but only a small group of practitioners mentioned any related concern. One reason can be the possibility of different perspectives on warehouse problems. According to one of the interviewees, if storage and picking are not done efficiently, the problem might be perceived as a space problem. Various picking methods, e.g., single order picking, batch picking and zone picking, are suggested in the literature, but their performance for different warehouse designs is a matter of debate. In addition to traditional evaluation of picking performance in terms of travel/ picking time, other criteria need to be investigated such as lead time, earliness and tardiness, which are important factors specifically when the warehouse is feeding a JIT system. Warehouse aisles are not usually very wide to let multiple pickers work together without interference. So, in case of planning picking operations for multiple pickers, one objective can be to minimize the congestion. One of the research streams in this category is to develop mathematical models for optimal picking path. The benefits of using optimized picking path for each pick list, versus having a generic route, can be investigated to understand when it is suitable to choose either of these two approaches. Considering the picking operations, one important task is to plan the sorting process, which is when items of different wave picks are traveling on conveyors and need to be sorted when coming to the accumulation point, so goods of each order list need to be sent to the assigned lane. Two decision problems should be investigated more: order of releasing picking waves and order-lane assignment. 


\subsubsection{Connection to other departments and companies}

Managing the connection of warehouse with other companies and departments is identified as an important issue by practitioners. But the corresponding research category is among those least investigated. Very few papers have focused on the interface of the warehouse with other departments and companies. The interaction of production and warehousing is the topic most investigated in this category, but there is a significant gap in the relation of warehouses and external companies. Different types of contract (e.g., wholesale price, capacity reservation, performance-based contract) and contract mechanisms need to be explored with both qualitative and quantitative approaches to identify potential benefits and concerns. Integrated planning of warehouse operations with other departments and companies needs a suitable structure of information sharing. It is important to identify what information and when it should be shared, and how to structure interfaces between client and provider of outsourced services (e.g., contracting performance or activities).

Table 7 Agenda for future research in warehousing

Positive approach
Operations strategy
Investigating how introduction of e-commerce and uncertain business
environment can influence operations strategies; analyzing the impact
of carbon emission regulation on choice of operations strategy
Infrastructure design
Exploring how risk management can be considered when designing the
warehouse

\section{Human resource management}

Understanding how warehousing job impacts workers mind and health; exploring opportunities and concerns of gender equity

\section{Technology and equipment}

Understanding how proper use of technology can be helpful to improve cooperation of warehouse and other companies/departments; investigating opportunities and challenges of employing cloud systems in WMSs

Performance evaluation

Investigating performance definition in the warehouses with different setups, type of work and responsibilities

\section{Receiving/shipping}

Identifying challenges and requirements of receiving/shipping operation

Storage

Exploring dynamic of goods in the warehouse to identify key factors of decision making on storage policy

\section{Picking}

Exploring how responsibilities and features of a warehouse can influence selection and evaluation of picking method; investigating how e-commerce can influence picking operation

\section{Connection to warehouse}

Understanding how connection of warehouse and other departments can be well established; exploring key factors facilitating collaboration of warehouse with external companies
Normative approach

Developing appropriate strategies and operational policies considering different industries and warehouse setups

Developing systematic approach to map interaction between departments; developing models to connect operations requirements and goods characteristics to warehouse design; analyzing the impact of different layout designs on environmental performance of the operations

Addressing appropriate procedures to track performance of personnel, schedule the workers considering different operations in the warehouse

Developing models to help selection of equipment; exploring mechanism to make the transition period smooth and efficient; analyzing decentralized control of automated equipment

Developing benchmarking studies in different industries and warehouse setups; cost modeling of warehouse operations; environmental performance evaluation of operations

Developing models/approaches to plan receiving/shipping in connection with other operations

Addressing models for storage policy selection and storage location assignment for different warehouse setups; developing models to plan the working process in relation with other operations and characteristics of the warehouse

Developing approaches to evaluate efficiency of picking strategies for different warehouse setups; developing models to plan picking operation including all the required components, e.g., batching, routing and sorting

Developing controlling mechanism for warehouse interface with other departments and companies; developing models to evaluate potential setup of the warehouse connection with others 


\subsection{An agenda for future research}

There is a huge gap between the number of papers with an assumption-restricted modeling approach and those based on the complex reality of warehouses. The lack of empirical research in this area can be considered as a warning to academia. More case and action research studies must be done, which can help the research community to better understand the reality. In addition, research results with a validity check on real-case settings will have direct benefits for practice.

The majority of the reviewed papers have mathematical modeling as their main research method, and the outcome of this research is usually sophisticated algorithms. Such methods need to be implanted in WMS for warehouses to use them. But according to the interviewees, most of the algorithms used in WMS are not really advanced, as advanced algorithms often need a lot of accurate data which are not usually available in practice. Hence, practitioners prefer to keep the logic of the solutions pretty simple to make sure they work in reality. Although consideration to global warming is an important trend in operations management literature, majority of the reviewed literature focused on economic efficiency in both warehouse design and operations. Papers with special focus on energy efficiency and environmental performance are very scarce. Surprisingly, this important issue was also almost neglected by interviewed practitioners. Many countries have introduced carbon emission regulation (e.g., cap-andtrade scheme in Europe and carbon tax in Australia), which emphasizes the importance of further research in this field. Opportunities and challenges of employing more advanced technologies, e.g., cloud-based technologies, were also missed by both practitioners and reviewed literature. Cloud-based technologies can be helpful in real-time data analysis and decision making. Although they facilitate information sharing, information security and performance of the system for huge volume of the data need to be investigated. Interviewees raised their concerns regarding occurrence of discrepancies in warehouse operations. One potential option to monitor and track such problems is to use cameras in the warehouse or on the equipment (e.g., forklifts), which can help monitoring and documentation of the procedures in the warehouse. This alternative was not suggested by either literature or practitioners. Effectiveness and possible problems of using such technologies need to be analyzed. According to the identified gaps in the literature and practitioners' input, a research agenda based on the categories in Fig. 1 is presented in Table 7.

Suggested research directions are divided into two areas; first, studies aiming to understand, explain and predict a concept or phenomenon that is currently practiced and exists (positive approach), and second, research attempting to provide guidelines to managers regarding what should be done (normative approach) [74]. The positive studies suggested can be done through survey, case and interview studies; normative studies include but are not limited to modeling studies. Our analysis shows that more empirical investigations should be conducted to understand and capture complexities of the real environment, and proposed normative studies need to be accompanied by practical applications to benefit both academia and practice.

\section{Conclusion}

From a research perspective, this study provides an agenda for future research based on the identified methodologywise and content-wise gaps as well as practitioners' concerns. Employing practitioners' input is one of the main features differentiating this study from its predecessors [2, $3,75]$. Combining these two methods allowed us to achieve higher practical and managerial relevance for the suggested potential future research in the warehousing field. If a category of research is prominent in the literature, it means the topic is interesting for scholars but not necessarily important for industry. On the other hand, if literature lacks research in a particular field, it cannot be directly viewed as a great opportunity for future research. Weakness of the literature in that field may be due to lack of interest or (assumed) practical importance. By employing two methods, both a literature review and analysis of practitioners' insights, the proposed agenda for future research is not only based on the identified gaps in the literature but also considers the input from industry. These two methods play complementary roles. Although performed interviews are not enough to build the foundation for theory building, they can provide a "springboard" for future research [11]. The results of this study reveal a lack of reality-based investigations. Most of the scholars focus on quantitative research methods and mathematical modeling without any examples from real cases. This fact makes it considerably difficult to apply the researches performed to practice. While it is believed that the warehousing researchers have taken considerable steps to expand the boundaries of literature, the suggested agenda emphasizes reality-based relevant research for the future. Economic efficiency is the most highlighted goal in warehousing literature, while energy efficiency and environmental performance have gained increasing attention during past couple of decades in operations management literature.

The suggested agenda is based on literature gaps and practitioners' insights. Analyzing affiliation of the authors reveals a huge imbalance between volume of the related research in developed and developing countries. The majority of the reviewed literature originates from 
developed countries, the same as our interviewed practitioners. This fact opens up further opportunities for future research. Globalization and outsourcing operations to countries with less expensive labor and other environment might stress challenges to warehousing business which might have been overlooked in the reviewed literature and by interviewed practitioners, e.g., regarding reliability, security and IT-security.

Acknowledgment The authors are gtrateful to Prof Herbert Kotzab, the associate editor, and the two anonymous referees for their valuable comments and suggestions that significantly improved this study.

Open Access This article is distributed under the terms of the Creative Commons Attribution License which permits any use, distribution, and reproduction in any medium, provided the original author(s) and the source are credited.

\section{References}

1. Carter CR (2008) Knowledge production and knowledge transfer: closing the research-practice gap. J Supply Chain Manag 44(2):78-82

2. Gu J, Goetschalckx M, McGinnis LF (2007) Research on warehouse operation: a comprehensive review. Eur J Oper Res 177(1):1-21. doi:10.1016/j.ejor.2006.02.025

3. Gu J, Goetschalckx M, McGinnis LF (2010) Research on warehouse design and performance evaluation: a comprehensive review. Eur J Oper Res 203(3):539-549. doi:10.1016/j.ejor.2009. 07.031

4. Tranfield D, Denyer D, Smart P (2003) Towards a methodology for developing evidence-informed management knowledge by means of systematic review. Br J Manag 14(3):207-222

5. Rowley J, Slack F (2004) Conducting a literature review. Manag Res News 27(6):31-39

6. Saunders M, Lewis P, Thornhill A (2009) Research methods for business students. Pearson, Harlow

7. Bartholdi JJ, Hackman ST (2010) Warehouse and distribution science, release 0.93. Georgia Institute of Technology, Atlanta, USA. Available at: http://www.warehouse-science.com. Accessed Oct 2011

8. Baker P, Canessa M (2009) Warehouse design: a structured approach. Eur J Oper Res 193(2):425-436. doi:10.1016/j.ejor. 2007.11.045

9. Thomas RW, Defee CC, Randall WS, Williams B (2011) Assessing the managerial relevance of contemporary supply chain management research. Int J Phys Distrib Logist Manag 41(7):655-667

10. Sodhi MS, Son B-G, Tang CS (2012) Researchers' perspectives on supply chain risk management. Prod Oper Manag 21(1):1-13

11. Bryman A, Bell E (2003) Business research methods. Oxford University Press, Oxford

12. Baker $P$ (2008) The design and operation of distribution centres within agile supply chains. Int J Prod Econ 111(1):27-41. doi:10. 1016/j.ijpe.2006.09.019

13. Klingenberg W, Boksma JD (2010) A conceptual framework for outsourcing of materials handling activities in automotive: differentiation and implementation. Int J Prod Res 48(16):4877-4899. doi: $10.1080 / 00207540903067177$

14. Lee CC (2006) Two-warehouse inventory model with deterioration under FIFO dispatching policy. Eur J Oper Res 174(2): 861-873. doi:10.1016/j.ejor.2005.03.027
15. Wang H, Chen S, Xie Y (2010) An RFID-based digital warehouse management system in the tobacco industry: a case study. Int J Prod Res 48(9):2513-2548. doi:10.1080/00207540903564918

16. Tse YK, Tan KH, Ting SL, Choy KL, Ho GTS, Chung SH (2012) Improving postponement operation in warehouse: an intelligent pick-and-pack decision-support system. Int J Prod Res 50(24): 7181-7197

17. Lee MK, Elsayed EA (2005) Optimization of warehouse storage capacity under a dedicated storage policy. Int $\mathrm{J}$ Prod Res 43(9):1785-1805. doi:10.1080/13528160412331326496

18. Zhang GQ, Xue J, Lai KK (2000) A genetic algorithm based heuristic for adjacent paper-reel layout problem. Int J Prod Res 38(14):3343-3356

19. Caron F, Marchet G, Perego A (2000) Optimal layout in lowlevel picker-to-part systems. Int J Prod Res 38(1):101-117

20. Malmborg CJ (2001) Rule of thumb heuristics for configuring storage racks in automated storage and retrieval systems design. Int J Prod Res 39(3):511-527

21. Al-Araidah O, Krishnamurthy A, Malmborg CJ (2007) A comparative study of single-phase and two-phase approaches for the layout problem with material handling costs. Int J Prod Res 45(4):951-970. doi:10.1080/00207540600635169

22. Heragu SS, Du L, Mantel RJ, Schuur PC (2005) Mathematical model for warehouse design and product allocation. Int J Prod Res 43(2):327-338. doi:10.1080/00207540412331285841

23. Önüt S, Tuzkaya UR, Doğaç B (2008) A particle swarm optimization algorithm for the multiple-level warehouse layout design problem. Comput Ind Eng 54(4):783-799. doi:10.1016/j. cie.2007.10.012

24. Roodbergen KJ, Sharp GP, Vis IFA (2008) Designing the layout structure of manual order picking areas in warehouses. IIE Trans (Inst Ind Eng) 40(11):1032-1045. doi:10.1080/074081708021 67639

25. Cook P, Sproul A (2011) Towards low-energy retail warehouse building. Archit Sci Rev 54(3):206-214. doi:10.1080/00038628. 2011.590055

26. Dhooma J, Baker P (2012) An exploratory framework for energy conservation in existing warehouses. Int J Logist Res Appl 15(1):37-51. doi:10.1080/13675567.2012.668877

27. Rai D, Sodagar B, Fieldson R, $\mathrm{Hu} X$ (2011) Assessment of $\mathrm{CO}_{2}$ emissions reduction in a distribution warehouse. Energy 36(4):2271-2277. doi:10.1016/j.energy.2010.05.006

28. Bard JF, Wan L (2005) Weekly scheduling in the service industry: an application to mail processing and distribution centers. IIE Trans (Inst Ind Eng) 37(5):379-396. doi:10.1080/ 07408170590885288

29. Min H (2007) Examining sources of warehouse employee turnover. Int J Phys Distrib Logist Manag 37(5):375-388. doi:10. 1108/09600030710758437

30. Butler HL, Hubley-Kozey CL, Kozey JW (2007) Changes in trunk muscle activation and lumbar-pelvic position associated with abdominal hollowing and reach during a simulated manual material handling task. Ergonomics 50(3):410-425. doi:10.1080/ 00140130601128081

31. Chakravorty SS (2009) Improving distribution operations: implementation of material handling systems. Int J Prod Econ 122(1):89-106

32. Wagner DW, Reed MP, Chaffin DB (2010) The development of a model to predict the effects of worker and task factors on foot placements in manual material handling tasks. Ergonomics 53(11):1368-1384. doi:10.1080/00140139.2010.523482

33. Plamondon A, Larivière C, Delisle A, Denis D, Gagnon D (2012) Relative importance of expertise, lifting height and weight lifted on posture and lumbar external loading during a transfer task in manual material handling. Ergonomics 55(1):87-102. doi:10. 1080/00140139.2011.634031 
34. Dadzie KQ, Lee E, Dadzie EW (2000) Assessing logistics technology adoption time with event history analysis. Int $\mathrm{J}$ Logist Manag 11(1):47-60

35. Tuzkaya G, Gülsün B, Kahraman C, Özgen D (2010) An integrated fuzzy multi-criteria decision making methodology for material handling equipment selection problem and an application. Expert Syst Appl 37(4):2853-2863. doi:10.1016/j.eswa. 2009.09.004

36. Shiau JY, Lee MC (2010) A warehouse management system with sequential picking for multi-container deliveries. Comput Ind Eng 58(3):382-392. doi:10.1016/j.cie.2009.04.017

37. Usher JS, Kamal AH, Kim SW (2001) Decision support system for economic justification of material handling investments. Comput Ind Eng 39(1-2):35-47. doi:10.1016/s0360-8352(00) 00064-4

38. Poon TC, Choy KL, Chow HKH, Lau HCW, Chan FTS, Ho KC (2009) A RFID case-based logistics resource management system for managing order-picking operations in warehouses. Expert Syst Appl 36(4):8277-8301. doi:10.1016/j.eswa.2008.10.011

39. Chow HKH, Choy KL, Lee WB, Lau KC (2006) Design of a RFID case-based resource management system for warehouse operations. Expert Syst Appl 30(4):561-576. doi:10.1016/j.eswa. 2005.07.023

40. Vijayaraman BS, Osyk BA (2006) An empirical study of RFID implementation in the warehousing industry. Int J Logist Manag 17(1):6-20

41. Berman S, Edan Y (2002) Decentralized autonomous AGV system for material handling. Int $\mathrm{J}$ Prod Res 40(15 SPEC.): 3995-4006. doi:10.1080/00207540210146990

42. Berman S, Edan Y, Jamshidi M (2003) Navigation of decentralized autonomous automatic guided vehicles in material handling. IEEE Trans Robot Autom 19(4):743-749. doi:10.1109/tra. 2003.814513

43. Butler LJ, Bright G (2010) Control strategy for a mobile selfbalancing materials handling platform. J Eng Des Technol 8(1):6-27. doi:10.1108/17260531011034628

44. Yang YC, Lin CL (2013) Performance analysis of cargo-handling equipment from a green container terminal perspective. Transp Res Part D Transp Environ 23:9-11. doi:10.1016/j.trd.2013.03. 009

45. Korpela J, Lehmusvaara A, Nisonen J (2007) Warehouse operator selection by combining AHP and DEA methodologies. Int J Prod Econ 108(1-2):135-142. doi:10.1016/j.ijpe.2006.12.046

46. Sohn SY, Han HK, Jeon HJ (2007) Development of an Air force warehouse logistics index to continuously improve logistics capabilities. Eur J Oper Res 183(1):148-161. doi:10.1016/j.ejor. 2006.09.073

47. Van Nieuwenhuyse I, de Koster RBM (2009) Evaluating order throughput time in 2-block warehouses with time window batching. Int J Prod Econ 121(2):654-664. doi:10.1016/j.ijpe. 2009.01.013

48. Hwang HS, Cho GS (2006) A performance evaluation model for order picking warehouse design. Comput Ind Eng 51(2):335-342. doi:10.1016/j.cie.2005.10.002

49. Park BC, Foley RD, White JA, Frazelle EH (2003) Dual command travel times and miniload system throughput with turnoverbased storage. IIE Trans (Inst Ind Eng) 35(4):343-355

50. Meller RD, Klote JF (2004) A throughput model for carousel/ VLM pods. IIE Trans (Inst Ind Eng) 36(8):725-741

51. Hur S, Lee YH, Lim SY, Lee MH (2004) A performance estimation model for AS/RS by M/G/1 queuing system. Comput Ind Eng 46(2):233-241

52. Koh SG, Kim BS, Kim BN (2002) Travel time model for the warehousing system with a tower crane $\mathrm{S} / \mathrm{R}$ machine. Comput Ind Eng 43(3):495-507
53. Lao SI, Choy KL, Ho GTS, Tsim YC, Poon TC, Cheng CK (2012) A real-time food safety management system for receiving operations in distribution centers. Expert Syst Appl 39(3): 2532-2548. doi:10.1016/j.eswa.2011.08.105

54. Oh Y, Hwang H, Cha CN, Lee S (2006) A dock-door assignment problem for the Korean mail distribution center. Comput Ind Eng 51(2):288-296. doi:10.1016/j.cie.2006.02.009

55. Gagliardi JP, Ruiz A, Renaud J (2008) Space allocation and stock replenishment synchronization in a distribution center. Int J Prod Econ 115(1):19-27. doi:10.1016/j.ijpe.2008.04.006

56. Ho YC, Chien SP (2006) A comparison of two zone-visitation sequencing strategies in a distribution centre. Comput Ind Eng 50(4):426-439. doi:10.1016/j.cie.2005.11.002

57. Li ML (2009) Goods classification based on distribution center environmental factors. Int J Prod Econ 119(2):240-246. doi:10. 1016/j.ijpe.2008.10.016

58. Zäpfel G, Wasner M (2006) Warehouse sequencing in the steel supply chain as a generalized job shop model. Int J Prod Econ 104(2):482-501. doi:10.1016/j.ijpe.2004.10.005

59. Lerher T, Potrč I, Šraml M, Tollazzi T (2010) Travel time models for automated warehouses with aisle transferring storage and retrieval machine. Eur J Oper Res 205(3):571-583. doi:10.1016/j. ejor.2010.01.025

60. Van den Berg JP, Gademann AJRM (2000) Simulation study of an automated storage/retrieval system. Int J Prod Res 38(6): $1339-1356$

61. Oliveira JA (2007) Scheduling the truckload operations in automatic warehouses. Eur J Oper Res 179(3):723-735. doi:10.1016/ j.ejor.2005.03.066

62. Lam CHY, Choy KL, Ho GTS, Chung SH (2012) A hybrid caseGA-based decision support model for warehouse operation in fulfilling cross-border orders. Expert Syst Appl 39(8):7015-7028. doi:10.1016/j.eswa.2012.01.046

63. Chen MC, Huang CL, Chen KY, Wu HP (2005) Aggregation of orders in distribution centers using data mining. Expert Syst Appl 28(3):453-460. doi:10.1016/j.eswa.2004.12.006

64. Kim BI, Graves RJ, Heragu SS, Onge A (2002) Intelligent agent modeling of an industrial warehousing problem. IIE Trans (Inst Ind Eng) 34(7):601-612

65. Roodbergen KJ, De Koster R (2001) Routing methods for warehouses with multiple cross aisles. Int $\mathrm{J}$ Prod Res 39(9):1865-1883. doi:10.1080/00207540110028128

66. Theys C, Bräysy O, Dullaert W, Raa B (2010) Using a TSP heuristic for routing order pickers in warehouses. Eur J Oper Res 200(3):755-763. doi:10.1016/j.ejor.2009.01.036

67. Curry GL, Peters BA, Lee M (2003) Queueing network model for a class of material-handling systems. Int $J$ Prod Res 41(16):3901-3920. doi:10.1080/0020754031000149293

68. Van den Berg JP (2002) Analytic expressions for the optimal dwell point in an automated storage/retrieval system. Int J Prod Econ 76(1):13-25

69. Won J, Olafsson S (2005) Joint order batching and order picking in warehouse operations. Int J Prod Res 43(7):1427-1442. doi:10. 1080/00207540410001733896

70. Poon TC, Choy KL, Cheng CK, Lao SI, Lam HY (2011) Effective selection and allocation of material handling equipment for stochastic production material demand problems using genetic algorithm. Expert Syst Appl 38(10):12497-12505. doi:10.1016/j. eswa.2011.04.033

71. Chou YC, Chen YH, Chen HM (2012) Recency-based storage assignment and warehouse configuration for recurrent demands. Comput Ind Eng 62(4):880-889. doi:10.1016/j.cie.2011.12.009

72. Hill J, Galbreth M (2008) A heuristic for single-warehouse multiretailer supply chains with all-unit transportation cost discounts. Eur J Oper Res 187(2):473-482. doi:10.1016/j.ejor.2007.03.015 
73. Chen FY, Hum SH, Sun J (2001) Analysis of third-party warehousing contracts with commitments. Eur J Oper Res 131(3): 603-610

74. Juttner U, Peck H, Christopher M (2003) Supply chain risk management: outlining an agenda for future research. Int J Logist Res Appl 6(4):197-210
75. Gong Y, de Koster RM (2011) A review on stochastic models and analysis of warehouse operations. Logist Res 3(4):191-205. doi:10.1007/s12159-011-0057-6 